\title{
The activity of cathepsin D and alpha-1 antitrypsin in hip and knee osteoarthritis
}

\author{
Dorota Olszewska-Slonina1 ${ }^{\bowtie}$, Dariusz Matewski², Stanislaw Jung ${ }^{3}$, Krzysztof J. Olszewski², \\ Rafal Czajkowski ${ }^{4}$ Joanna Braszkiewicz ${ }^{5}$, Alina Wozniak ${ }^{4}$ and Bogna Kowaliszyn ${ }^{6}$
}

'Laboratory of Cell Biology and Genetics, Collegium Medicum in Bydgoszcz, Nicolaus Copernicus University in Torun, Bydgoszcz, Poland; 2 Department of Orthopaedics and Traumatology, Collegium Medicum in Bydgoszcz, Nicolaus Copernicus University in Torun, Bydgoszcz, Poland; 3Department of Orthopaedics, South Tyneside District Hospital in South Shields, United Kingdom: ${ }^{4}$ Department of Medical Biology, Collegium Medicum in Bydgoszcz, Nicolaus Copernicus University in Torun, Bydgoszcz, Poland; ${ }^{5}$ Vitalabo Analytical Laboratory, Bydgoszcz, Poland; ${ }^{6}$ Department of Genetics and General Animal Breeding, Faculty of Animal Breeding and Biology, University of Technology and Life Sciences, Bydgoszcz, Poland

The progress of cartilage decay during joint degeneration is not well monitored with biochemical methods. The role of cathepsin D (CAT-D) in articular cartilage deterioration remains unclear. The aim of this study is to assess the activity of CAT-D and alpha- 1 antitrypsin (AAT) in blood in patients with hip or knee osteoarthritis. The activity of CAT-D and AAT in blood serum of $\mathbf{4 0}$ women and $\mathbf{2 1}$ men with hip or knee osteoarthritis was determined before total joint replacement, on the tenth day after surgery, and once in 54 healthy patients. The preoperative activity of CAT-D in patients with osteoarthritis was lower by $53.6 \%\left(11.00 \pm 4.5410^{-2} \mathrm{nM}\right.$ released tyrosine $/ \mathrm{mg}$ protein $/ \mathrm{min}, P<0.001)$ and after surgery by $55.0 \%\left(10.67 \pm 4.6410^{-2} \mathrm{nM}\right.$ released tyrosine/mg protein/min, $P<0.001)$ when compared to its activity in healthy patients. There was no significant statistical difference between CAT-D activity before the surgery and its activity on the tenth day after it in the analyzed group $(P<0.496)$. Simultaneously, the preoperative activity of AAT in the OA (osteoarthritis) patients was by $25.5 \%(0.93 \pm 0.32 \mathrm{mg}$ inhibited trypsin $/ \mathrm{ml}$ blood serum, $P<0.001)$ and postoperative was by $44.9 \%$ higher $(1.26 \pm 0.36 \mathrm{mg}$ inhibited trypsin $/ \mathrm{ml}$ blood serum, $P<0.001)$ than in healthy patients. The low CAT-D activity in osteoarthritis of big joints is associated with a decrease of cartilage cells during the degenerative process. The higher activity of acute phase protein AAT in OA patients' blood serum confirms the inflammatory component in the osteoarthritis process.

Key words: cathepsin D; alpha 1-antitrypsin; protease; antiprotease; osteoarthritis; cartilage

Received: 31 October, 2012; revised: 11 March, 2013; accepted: 18 March, 2013; available on-line: 21 March, 2013

\section{INTRODUCTION}

Osteoarthritis (OA) of big joints (hip, knee) constitutes both medical and economic problem in aging population of industrialized countries. The prevalence of hip $\mathrm{OA}$ is about $3 \%$ to $6 \%$ in the Caucasian population (Hoaglund \& Steinbach, 2001).

Unlike other biological processes that are reflected in enzymatic activity, there are few biochemical markers used for diagnosis and monitoring of the joint degenerative process, like osteocalcin or bone alkaline phosphatase (Schneider et al., 2002; Garnero \& Delmas,
2003; Lis et al., 2006). It is generally accepted that OA is accompanied by inflammation. This synovitis causes joint damage (Brooks, 2003; Bonnet \& Walsh, 2005).

In OA resulting from inflammatory processes both the erythrocyte sedimentation rate (ESR) and C-reactive protein (CRP) in blood serum are significantly increased (Stürmer et al., 2004). On the contrary, even in the most advanced cases of joint degeneration with no signs of inflammation, only a small increase of the ESR occurs (Pearle et al., 2007). The articular cartilage decays during the degeneration process and eventually it is totally removed with subchondral bone at the time of total joint replacement. Two major components of the cartilage matrix, proteoglycan and collagen, disappear with the proteoglycan being lost first. The cause of cartilage damage, apart from mechanical incongruence remains unclear; some substances released either from cartilage, synovium, or from joint fluid cells are considered. The previous work has demonstrated that the intrinsic cartilage enzymes might be responsible for the eventual destruction (Bowe et al., 2007).

Cathepsin D (CAT-D, EC 3.4.23.5), a lysosomal aspartic protease, is a vital indicator of the degree of lysosomal damage, especially in oxygen deficiency, cell decay, and necrosis (Stoka et al., 2007). This proteinase together with other proteolytic enzymes take part in an intracellular digestion of proteoglycan in the initial stages of osteoarticular inflammation (Handley et al., 2001; RuizRomero et al., 2005). A proteoglycan matrix damage allows CAT-D to enter the joint fluid leading to the deterioration of articular cartilage (Olszewska et al., 2001). New reports (Bao et al., 2010) added more information on the possible influence of leptin on the increased activity of proteolytic enzymes such as CAT-D.

Alpha-1 antitrypsin (AAT), an antiprotease, protects tissues from uncontrolled proteolysis damage. The protease-antiprotease balance is maintained by the inhibitory properties of AAT. AAT accounts for $80-90 \%$ of the blood antiprotease activity (Karnaukhova et al., 2006). Fischer et al. (1999) showed that AAT, acute-phase protein, a major inhibitor of serine proteinases, also protects cartilage chondrocytes from the destructive CAT-D ac-

e-mail: dorolsze@poczta.onet.pl

Abbreviations: AAT, alpha-1 antitrypsin; AS, ankylosing spondylitis; CAT-D, cathepsin D; CRP, C-reactive protein; ESR, erythrocyte sedimentation rate; $\mathrm{OA}$, osteoarthritis; $\mathrm{RA}$, rheumatoid arthritis 
tion. Thus, one may expect that the decrease of AAT activity results in the loss of chondroprotection.

The aim of this study is to assess the activity of CAT$\mathrm{D}$ and its antiprotease AAT in blood in patients with hip and knee osteoarthritis.

\section{MATERIALS AND METHODS}

Subjects. The study included 40 women aged 46-78 (mean age: $65.8 \pm 10.2$ ) and 21 men aged 40-77 (mean age: $58.6 \pm 10.5$ ) with diagnosed degenerative disease (OA) of hip or knee joint who had been treated in the Department of Orthopedics and Traumatology, the Ludwik Rydygier Collegium Medicum in Bydgoszcz, Poland, from September 2004 to December 2006. The diagnosis of OA was set based on history, clinical and radiological examination. To assess the degree of OA the KellgrenLawrence scale was applied. The inclusion criteria for total joint replacement were history of pain lasting longer than 6 months and advanced radiological changes (grade III or IV). We excluded patients who had any current source of inflammation other than affected joint, or have had such during last 4 weeks.

Hip osteoarthritis was reported in 31 women (among them 6 with two joints affected) and 15 men $(3-$ two joints involved); and OA of knee in 9 women (5 - two joints involved) and 6 men (2 patients with bilateral presentation). Among 61 patients included in the study 13 were smokers.

The reference group of healthy volunteers consisted of 28 women aged $24-86$ (mean age $63.1 \pm 14.0$ ) and 26 men aged 32-89 (mean age 62.8 \pm 14.1 ). The inclusion criteria to the reference group were no past history of any musculoskeletal disorders nor diseases, and no clinical signs of $\mathrm{OA}$ with normal range of joint movement. The research was approved by the Local Bioethics Committee and all patients have signed an informed consent.

All patients were treated in the Department of Orthopedics and Traumatology.

We performed 15 cemented total knee replacements, 24 cemented total hip replacements and 22 hips with cementless technique. Mean duration of hip surgery was $89.0 \pm 16.8 \mathrm{~min}$ and of knee $-168.8 \pm 22.0 \mathrm{~min}$. The median of CRP (C-reactive protein) in hip OA patients was $2.6 \mathrm{mg} / \mathrm{l}$ (range $0.5-15.5 \mathrm{mg} / \mathrm{l}$ ) and in knee OA patients - median $4.5 \mathrm{mg} / 1$ (range 0.5-24.6 $\mathrm{mg} / \mathrm{l})$. In early postoperative time there were four complications: 1 bronchitis, 1 superficial wound infection, 1 dental infection and a gastric ulcer hemorrhage. All these complications occurred after hip replacement.

Sample collection. Blood samples were taken from fasting patients from the ante cubital vein during aroutine check and kept in dry and sterile test-tubes (Grainer Bio-one, Kremsmünster Austria). The blood was taken twice - once before the total joint replacement and again on the tenth day after the surgery. In healthy patients the blood was taken once during routine medical examinations at the time of the study.

Sample assays and serum preparation were completed in the university laboratory within two hours after the collection. Each blood sample, after complete clotting, was centrifuged for $10 \mathrm{~min}$ at $3000 \times \mathrm{g}$, at the temperature of $4^{\circ} \mathrm{C}$. Serum from the samples was taken into Eppendorf test tubes and kept frozen at $-80^{\circ} \mathrm{C}$ until the biochemical tests were performed, but for no longer than two months. Serum was defrosted approximately one hour before the assay.
Assays. Biochemical tests were performed in the Department of Medical Biology at Ludwik Rydygier Collegium Medicum in Bydgoszcz.

Determinig CAT-D activity. CAT-D activity was determined by Anson's method in a citrate-phosphorous buffer of $\mathrm{pH} 3.8$ in the presence of $2 \%$ denatured bovine haemoglobin (substrate) (Mycek, 1970). The activity of the enzyme was shown by the amount of tyrosine released during enzymatic hydrolysis of the substratum. Extinction of the samples was checked after $15 \mathrm{~min}$ at the wavelength of $660 \mathrm{~nm}$ and compared to blind test. Enzyme's activity measured in samples was given in $10^{-2}$ $\mathrm{nM}$ released tyrosine $/ \mathrm{mg}$ protein $/ \mathrm{min}$, expressed as the mean value of three consecutive measurements.

Determining AAT activity. Activity of AAT in blood serum was measured by Eriksson's method (Szczeklik, 1974). The decrease of trypsin's enzymatic activity was caused by short incubation with defibrinated serum. Samples' absorbance was checked at wavelength $\lambda=410 \mathrm{~nm}$ and compared to blind test and AAT activity from the samples was measured in mg of inhibited tryp$\sin / \mathrm{ml}$ of serum.

Statistical analysis. All results were compared by the Statistic Package for Social Sciences (SPSS Inc., Chicago, USA, version 17.0). Shapiro-Wilk's test was applied for the compatibility estimation of the assessed parameters distribution with normal distribution. All results were expressed as mean \pm S.D. The differences between groups were assessed using non-parametric KolmogorovSmirnov test and Mann-Whitney U-test - to compare OA groups to a reference one. Wilcoxon test was used to compare pre- and postoperative enzyme activities; Kruskal-Wallis test was applied to compare three or more groups of sample data. Pearson correlation coefficients were used to assess the relationship between parameters. Two-tailed $P$ value of $<0.05$ was considered statistically significant.

\section{RESULTS}

There was no statistical difference between the age of OA patients and healthy patients $(P=0.993)$. In the OA patients there was a significant difference between women and men $(P=0.018)$; such statistical difference was not found in healthy participants of this study (males/ females $P=0.802$ ).

The preoperative activity of CAT-D in patients with $\mathrm{OA}$ of the hip and knee was $11.00 \pm 4.5410^{-2} \mathrm{nM}$ released tyrosine $/ \mathrm{mg}$ protein $/ \mathrm{min}$ and on the 10 th day after $-10.67 \pm 4.6410^{-2} \mathrm{nM}$ released tyrosine $/ \mathrm{mg}$ protein $/ \min (r=0.207, P=0.154)$. Both these values were significantly lower when compared with CAT-D activity in healthy patients $\left(23.69 \pm 13.0610^{-2} \mathrm{nM}\right.$ released tyrosine/mg protein/min, $P<0.001$ ) (Table 1). This was true for both male and female patients. In female patients the activity of CAT-D before surgery was $10.95 \pm 5.2210^{-2}$ $\mathrm{nM}$ released tyrosine $/ \mathrm{mg}$ protein $/ \mathrm{min}$, and $9.88 \pm 3.23$ $10^{-2} \mathrm{nM}$ released tyrosine/ $\mathrm{mg}$ protein/min after surgery ( $r=0.258, P=0.168$, Table 1). Both these values were significantly lower when compared with CAT-D activity in the healthy patients $\left(23.06 \pm 12.1810^{-2} \mathrm{nM}\right.$ released tyrosine/mg protein $/ \mathrm{min}, P<0.001)$. In male patients the activity of CAT-D before surgery was $11.10 \pm 2.8910^{-2}$ $\mathrm{nM}$ released tyrosine $/ \mathrm{mg}$ protein $/ \mathrm{min}$ and $11.85 \pm 6.09$ $10^{-2} \mathrm{nM}$ released tyrosine $/ \mathrm{mg}$ protein $/ \mathrm{min}$ after surgery ( $r=0.454, P=0.051$, Table 1). Both these values were significantly lower when compared with CAT-D activity in the healthy patients $\left(24.37 \pm 14.1610^{-2} \mathrm{nM}\right.$ released ty- 


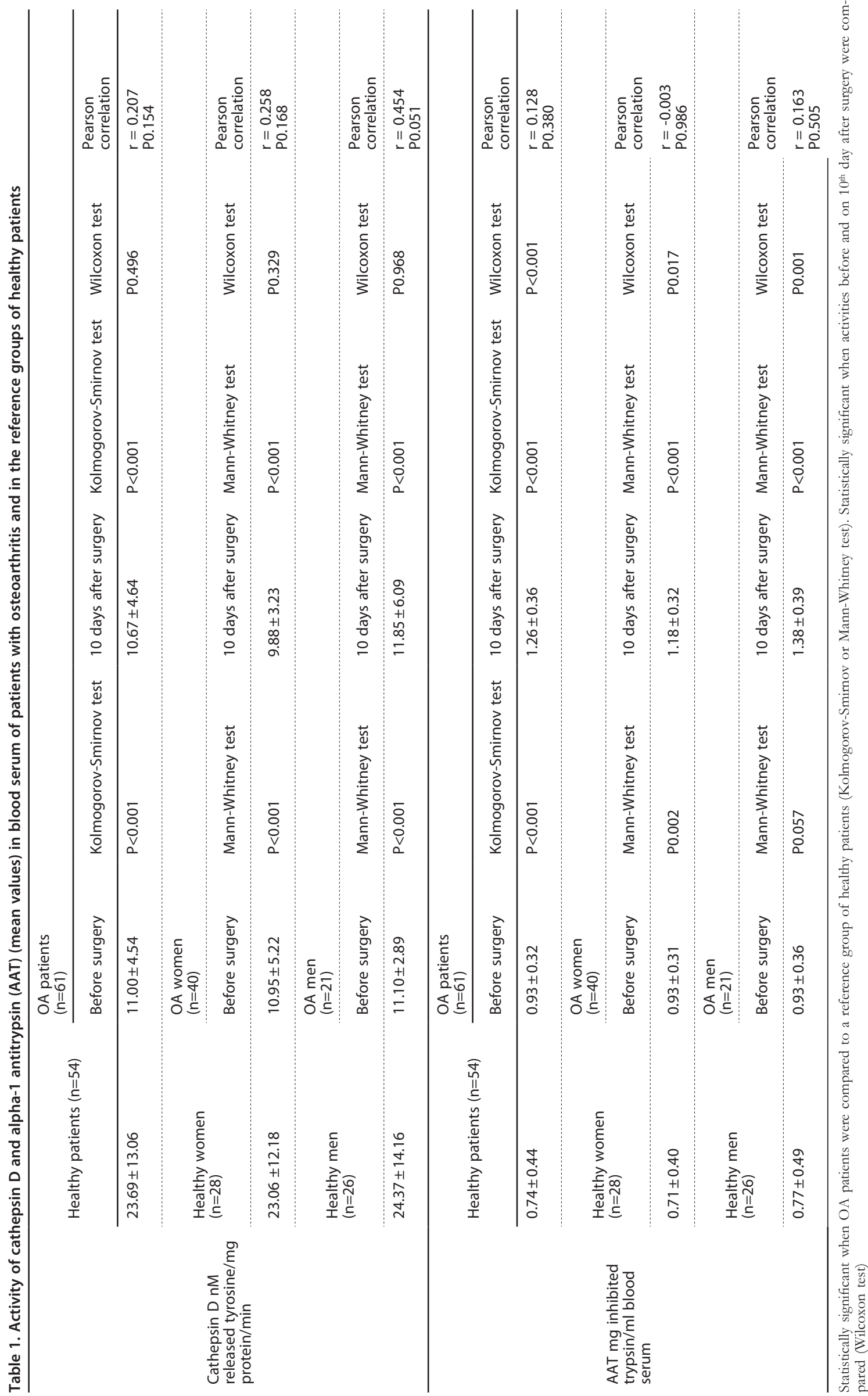


rosine $/ \mathrm{mg}$ protein $/ \mathrm{min}, P=0.002$ for preoperative values and $P<0.001$ after surgery).

The OA patients were divided also according to affected joint (Table 2) and to age and sex (Table 3).

When localization criteria were taken into account, the decrease of CAT-D activity was also visible in subjects with two knees involved, who had the initial activity of $8.53 \pm 3.0010^{-2} \mathrm{nM}$ released tyrosine/mg protein/ min when compared to healthy patients $(23.69 \pm 13.06$ $10^{-2} \mathrm{nM}$ released tyrosine $/ \mathrm{mg}$ protein $/ \mathrm{min}, \quad P<0.001$. Table 2).

In subjects with one knee involved, the initial activity of CAT-D was $13.48 \pm 2.1710^{-2} \mathrm{nM}$ released tyrosine/ $\mathrm{mg}$ protein/min and differed significantly from that of healthy patients $(P<0.001)$. In subjects with two hips involved, the initial activity of CAT-D was $11.11 \pm 4.03$ $10^{-2} \mathrm{nM}$ released tyrosine/ $\mathrm{mg}$ protein $/ \mathrm{min}$ and differed significantly from that of healthy patients $(P<0.001)$. In subjects with one hip involved, the initial activity of CAT-D was $1.04 \pm 5.0010^{-2} \mathrm{nM}$ released tyrosine/ $\mathrm{mg}$ protein $/ \mathrm{min}$ and differed significantly from that of healthy patients $(P<0.001)$.

The preoperative activity of CAT-D in the blood serum of OA women between 44-54 years was statistically lower than in the healthy female subgroup $\left(10.88 \pm 2.7410^{-2} \mathrm{nM}\right.$ released tyrosine/mg protein/ $\min$ vs $20.54 \pm 10.5710^{-2} \mathrm{nM}$ released tyrosine/mg protein/min, $P=0.016)$. The CAT-D activity in younger men (under 55 years) before surgery was lower than in healthy patients $\left(10.61 \pm 3.3610^{-2} \mathrm{nM}\right.$ released tyrosine/ $\mathrm{mg}$ protein/min vs $21.93 \pm 7.3110^{-2} \mathrm{nM}$ released tyrosine $/ \mathrm{mg}$ protein $/ \mathrm{min}, P=0.004$, (Table 3). Total joint replacement did not influence the CAT-D activity in younger men. Postoperatively CAT-D activity in this group was $10.61 \pm 1.1910^{-2} \mathrm{nM}$ released tyrosine/mg protein/min as compared with preoperative activity $10.61 \pm 3.3610^{-2} \mathrm{nM}$ released tyrosine $/ \mathrm{mg}$ protein $/ \mathrm{min}$ $(\mathrm{r}=0.152, P=0.745)$.

Simultaneously, the preoperative activity of CAT$\mathrm{D}$ in patients above 55 years old was also about two times lower in comparison to the healthy group both in women $\left(10.97 \pm 5.7210^{-2} \mathrm{nM}\right.$ released tyrosine/mg protein/min vs $24.07 \pm 12.8810^{-2} \mathrm{nM}$ released tyrosine $/ \mathrm{mg}$ protein $/ \mathrm{min}, P=0.001)$ and in men $\left(11.36 \pm 2.7210^{-2}\right.$ $\mathrm{nM}$ released tyrosine/mg protein/min vs $25.46 \pm 14.54$ $10^{-2} \mathrm{nM}$ released tyrosine $/ \mathrm{mg}$ protein $\left./ \mathrm{min}, P=0.015\right)$. The pre- and postoperative values of CAT-D activity in this age group of patients ( $>55$ years) did not reveal any statistically significant differences (women $\mathrm{r}=0.177$, $P=0.398$, men $\mathrm{r}=0.538, P=0.071)$. In OA female patients this postoperative activity correlated significantly with age $(r=0.415 ; P=0.023)$.

Preoperative AAT activity in OA patients was higher than in case ofhealthy patients $(0.93 \pm 0.32 \mathrm{mg}$ inhibited trypsin $/ \mathrm{ml}$ blood serum vs $0.74 \pm 0.44 \mathrm{mg}$ inhibited trypsin $/ \mathrm{ml}$ blood serum, $P<0.001)$. Postoperative AAT activity was higher than in the healthy patients $(1.26 \pm 0.36 \mathrm{mg}$ inhibited trypsin $/ \mathrm{ml}$ blood serum vs $0.74 \pm 0.44 \mathrm{mg}$ inhibited trypsin $/ \mathrm{ml}$ blood serum, $P<0.001$, Table 1). Surgical procedure increased AAT activity from $0.93 \pm 0.32 \mathrm{mg}$ inhibited trypsin $/ \mathrm{ml}$ blood serum to $1.26 \pm 0.36 \mathrm{mg}$ inhibited trypsin $/ \mathrm{ml}$ blood se$\operatorname{rum}(P<0.001)$.

The activity of AAT in the blood serum of women before the surgery was higher than in the healthy women subgroup $(0.93 \pm 0.31 \mathrm{mg}$ inhibited trypsin/ $\mathrm{ml}$ blood serum vs $0.71 \pm 0.40 \mathrm{mg}$ inhibited trypsin $/ \mathrm{ml}$ blood serum, $P=0.002)$. After the total joint replacement procedure, AAT activity raised more; it was higher as compared to preoperative state $(1.18 \pm 0.32 \mathrm{mg}$ inhibited trypsin $/ \mathrm{ml}$ blood serum vs $0.93 \pm 0.31 \mathrm{mg}$ inhibited trypsin/ml blood serum, $P=0.003$, Table 1$)$. No statistically significant $(P=0.057)$ differences in AAT activity of men's blood serum before the surgical treatment as compared to healthy men subgroup were found $(0.93 \pm 0.36$ $\mathrm{mg}$ inhibited trypsin/ $\mathrm{ml}$ blood serum vs $0.77 \pm 0.49 \mathrm{mg}$ inhibited trypsin $/ \mathrm{ml}$ blood serum). After the total joint replacement procedure, the AAT activity in OA men's blood serum was higher than in the healthy men subgroup $(1.38 \pm 0.39 \mathrm{mg}$ inhibited trypsin/ml blood serum vs $0.77 \pm 0.49 \mathrm{mg}$ inhibited trypsin/ml blood serum, $P<$ 0.001). Simultaneously the increase in AAT activity after surgical intervention in OA men was also statistically significant $(P=0.001)$ (Table 1$)$.

For the patients with unilateral hip OA the postoperative AAT activity was higher than prior to surgery $(1.12 \pm 0.31 \mathrm{mg}$ inhibited trypsin $/ \mathrm{ml}$ blood serum vs $0.88 \pm 0.24 \mathrm{mg}$ inhibited trypsin $/ \mathrm{ml}$ blood serum, $P<0.001)$. For the patients with both hips involved the postoperative AAT activity was higher than prior to surgery $(1.36 \pm 0.47 \mathrm{mg}$ inhibited trypsin $/ \mathrm{ml}$ blood serum vs $1.09 \pm 0.55 \mathrm{mg}$ inhibited trypsin $/ \mathrm{ml}$ blood serum, $P=0.314$ ) higher than before the surgical treatment (NS) (Table 2). Statistically significant differences between preoperative AAT activity and healthy patients were also found in the group of patients with knee joint degeneration, both in unilateral $(0.96 \pm 0.20 \mathrm{mg}$ inhibited trypsin $/ \mathrm{ml}$ blood serum vs $0.74 \pm 0.44 \mathrm{mg}$ inhibited trypsin/ml blood serum, $P=0.006)$ and in bilateral presentation $(0.90 \pm 0.32 \mathrm{mg}$ inhibited trypsin $/ \mathrm{ml}$ blood serum vs $0.74 \pm 0.54 \mathrm{mg}$ inhibited trypsin $/ \mathrm{ml}$ blood serum, $P=0.006$ ). For patients with bilateral knee OA the AAT activity was higher than prior to surgery $(1.49 \pm 0.48 \mathrm{mg}$ inhibited trypsin $/ \mathrm{ml}$ blood serum vs $0.90 \pm 0.32 \mathrm{mg}$ inhibited trypsin $/ \mathrm{ml}$ blood serum, $P=0.109)$. When preand postoperative AAT activities were compared, the statistically significant difference was found only in case of the unilateral hip OA $(\mathrm{P}<0.001)$.

The surgical treatment also caused changes in the AAT activity in patients aged 44-54 years. The preoperative activity of this enzyme was higher in this age group of women than within healthy women $(0.93 \pm 0.12 \mathrm{mg}$ inhibited trypsin $/ \mathrm{ml}$ blood serum vs $0.60 \pm 0.26 \mathrm{mg}$ inhibited trypsin $/ \mathrm{ml}$ blood serum, $P=0.012)$ and also in men with OA $(1.11 \pm 0.53 \mathrm{mg}$ inhibited trypsin $/ \mathrm{ml}$ blood serum vs $0.59 \pm 0.32 \mathrm{mg}$ inhibited trypsin $/ \mathrm{ml}$ blood serum, $P=0.015)$. The activity of this enzyme increased after surgery to $1.01 \pm 0.26 \mathrm{mg}$ inhibited trypsin $/ \mathrm{ml}$ blood serum in women and to $1.46 \pm 0.32 \mathrm{mg}$ inhibited trypsin $/ \mathrm{ml}$ blood serum in men. The preoperative activity of AAT in male patients above 55 years was lower in comparison to healthy patients $(1.11 \pm 0.53 \mathrm{mg}$ inhibited trypsin $/ \mathrm{ml}$ blood serum vs $0.59 \pm 0.32 \mathrm{mg}$ inhibited trypsin $/ \mathrm{ml}$ blood serum, $P=0.015)$. AAT activity in this age OA women group increased by $30 \%$ after total joint replacement, and in men by $59 \%$ in comparison to preoperative values. In OA women subgroup postoperative AAT activity increased with age $(\mathrm{r}=0.389 ; P=0.034)$. The similar correlation with age was observed in healthy female subgroup $(\mathrm{r}=0.402$; $P=0.003)$.

When analyzed the postoperative AAT and CAT-D activities a positive correlation between these enzymes' in OA women subgroup $(\mathrm{r}=0,581 ; P=0,001)$ was found; similar correlation was also noted in healthy female subgroup ( $\mathrm{r}=0.477, P=0.010)$. 
Table 2. Activity of cathepsin D and alpha-1 antitrypsin (AAT) in blood serum of OA patients divided according to invalid joint (studied groups) and in the reference group of healthy patients

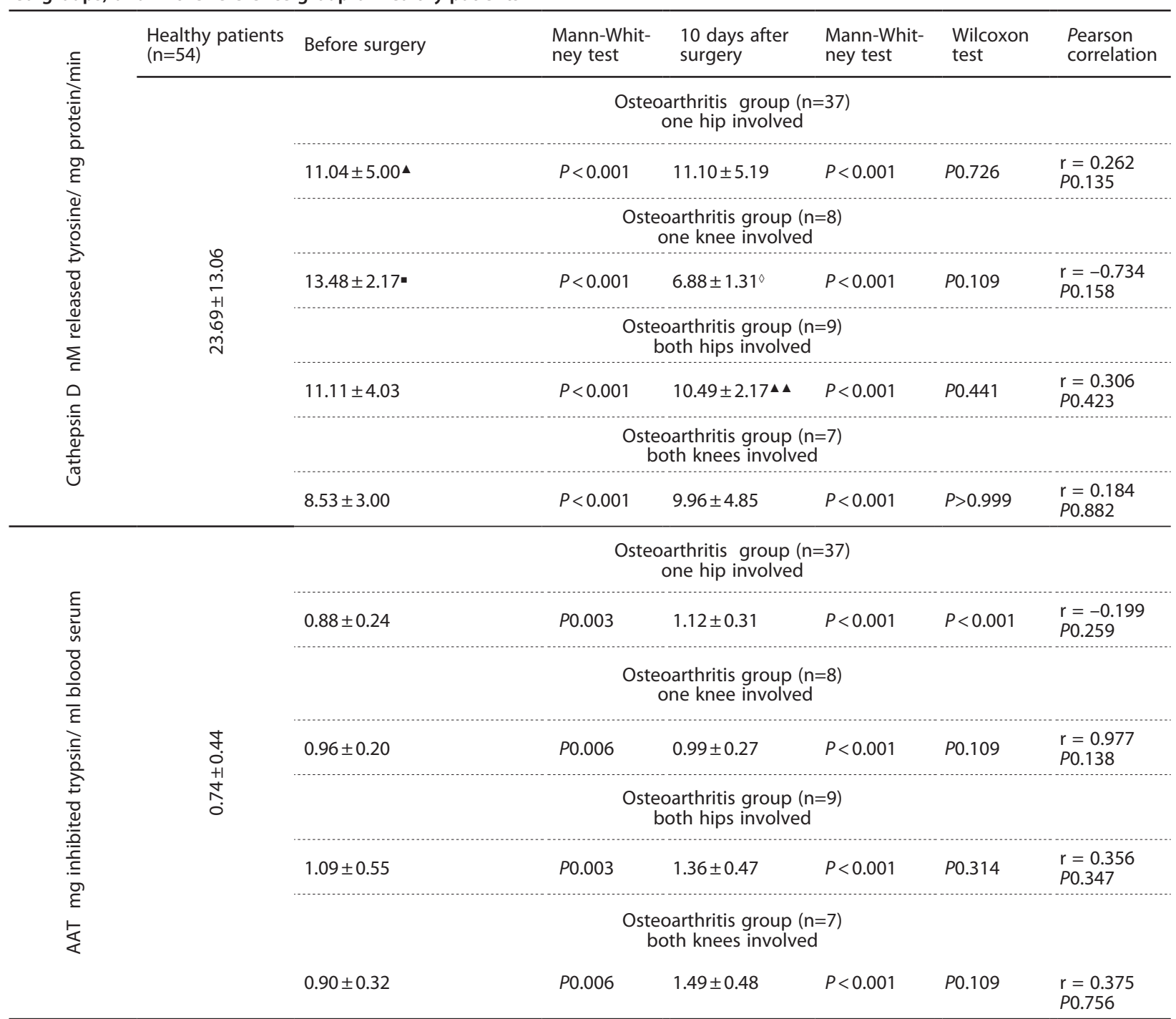

Statistically significant when OA patients were compared to a reference group of healthy patients (Mann-Whitney test). Statistically significant when activities before and on 10th day after surgery were compared (Wilcoxon test). Statistically significant (Kruskal-Wallis test) as compared to a OA patients of: one hip involved - P0.036; one knee involved $-\Delta P 0.036, \Delta \Delta P 0.021$; two hips involved $-{ }^{\wedge} P 0.021$; two knees involved nonsignificant

\section{DISCUSSION}

Poor proteolytic enzyme activity is a causative factor of the inflammatory process leading to OA. During the inflammatory process (rheumatoid arthritis or osteoarthritis) the cytokines (IL-1, IL- 6 and TNF- $\alpha$ ) are synthesized. Interleukin-6 (IL-6), one of the main markers of increased pro-inflammatory responses, stimulates the liver to produce acute phase proteins, such as AAT (Ucar et al., 2007). This, in turn, triggers the activity of proteolytic enzymes including CAT-D (Chevalier et al., 1996; Olewicz-Gawlik et al., 2004). Ruiz-Romero et al. (2005) and Keyszer et al. (1995) identified CAT-D in cartilage matrix and this enzyme is known to be the most abundant among other proteinases in synovial tissues.

Biological markers useful in OA progression monitoring are still being searched for (Bao et al., 2010). An inflammatory process with the protease-antiprotease balance disturbances and oxidative stress results in an irreversible changes in articular cartilage. All these processes influence CAT-D and AAT activities. Our findings sug- gest the possible role of an inflammatory process as an etiological factor in advanced degenerative joint disease. Recent report of the Sun showed an increased expression of ATA1 in synovial membranes of ankylosing spondylitis (AS) as compared with samples from rheumatoid arthritis (RA) and osteoarthritis (OA), suggesting that ATA1 is related to inflammation and new bone formation (Sun et al., 2012). Probably the local enzymatic response is more important than the systemic one for early postoperative functional recovery (Fischer et al., 1999). Popko et al. (2005) showed that in osteoarthrosis patients the concentration of $\mathrm{N}$-acetyl-beta-hexosoaminidase, a lysosomal enzyme taking part in degradation of glycosaminoglycans, glycoproteins and glycolipids, was about 30\% higher in synovial fluid than in blood serum. After total joint replacement the control of local inflammation may be much more important than the control of systemic inflammation.

The main limitation of the presented study is a relatively small number of subjects in subgroups. We were also unable to give reliable results on smoking and alco- 
Table 3. Activity of cathepsin D and alpha- 1 antitrypsin (AAT) in blood serum of OA patients divided according to age (below 55 year, above 55 year) and sex (studied groups) and in the reference group of healthy patients

\begin{tabular}{|c|c|c|c|c|c|c|c|}
\hline & & Before surgery & $\begin{array}{l}\text { Mann-Whit- } \\
\text { ney test }\end{array}$ & $\begin{array}{l}10 \text { days after } \\
\text { surgery }\end{array}$ & $\begin{array}{l}\text { Mann-Whit- } \\
\text { ney test }\end{array}$ & $\begin{array}{l}\text { Wilcoxon } \\
\text { test }\end{array}$ & $\begin{array}{l}\text { Pearson } \\
\text { correlation }\end{array}$ \\
\hline & \multicolumn{7}{|c|}{ Below 55 years } \\
\hline & $\begin{array}{l}\text { Healthy women } \\
(\mathrm{n}=8)\end{array}$ & $\begin{array}{l}\text { OA women } \\
(n=9)\end{array}$ & & & & & \\
\hline $\begin{array}{l}\text { Cathepsin D nM } \\
\text { released tyrosine/ } \\
\text { mg protein/min }\end{array}$ & $20.54 \pm 10.57 \square \square$ & $10.88 \pm 2.74$ & P0.016 & $8.62 \pm 3.62$ & P0.012 & $P 0.080$ & $\begin{array}{l}r=0.235 \\
P 0.703\end{array}$ \\
\hline \multirow[t]{2}{*}{$\begin{array}{l}\text { AAT } \mathrm{mg} \text { inhibited } \\
\text { trypsin/ } \mathrm{ml} \text { blood } \\
\text { serum }\end{array}$} & $0.60 \pm 0.26$ & $0.93 \pm 0.12$ & P0.012 & $1.01 \pm 0.26 *$ & P0.005 & $P=0.500$ & $\begin{array}{l}r=0.177 \\
P 0.775\end{array}$ \\
\hline & $\begin{array}{l}\text { Healthy men } \\
(n=8)\end{array}$ & $\begin{array}{l}\text { OA men } \\
(n=8)\end{array}$ & & & & & \\
\hline $\begin{array}{l}\text { Cathepsin } \mathrm{D} \text { nM } \\
\text { released tyrosine/ } \\
\text { mg protein/min }\end{array}$ & $21.93 \pm 7.31 \cdot \nabla$ & $10.61 \pm 3.36 \bullet \bullet$ & P0.004 & $10.61 \pm 1.19 \bullet \bullet \bullet \bullet$ & P0.006 & $P>0.999$ & $\begin{array}{l}r=0.152 \\
P 0.745\end{array}$ \\
\hline \multirow[t]{3}{*}{$\begin{array}{l}\text { AAT mg inhibited } \\
\text { trypsin/ ml blood } \\
\text { serum }\end{array}$} & $0.59 \pm 0.32=\nabla \nabla$ & $1.11 \pm 0.53 \bullet \bullet \bullet \bullet$ & $P 0.015$ & $1.46 \pm 0.32 \bullet \bullet$ & P0.004 & $P 0.043$ & $\begin{array}{l}r=0.704 \\
P 0.077\end{array}$ \\
\hline & \multicolumn{7}{|c|}{ Above 55 years } \\
\hline & $\begin{array}{l}\text { Healthy women } \\
(n=20)\end{array}$ & $\begin{array}{l}\text { OA women } \\
(n=31)\end{array}$ & & & & & \\
\hline $\begin{array}{l}\text { Cathepsin D nM } \\
\text { released tyrosine/ } \\
\text { mg protein/min }\end{array}$ & $24.07 \pm 12.88=\nabla$ & $10.97 \pm 5.72 \bullet \bullet 0$ & $P 0.001$ & $10.13 \pm 3.17 \bullet \diamond$ & $P<0.001$ & P0.696 & $\begin{array}{l}r=0.177 \\
P 0.398\end{array}$ \\
\hline \multirow[t]{2}{*}{$\begin{array}{l}\text { AAT mg inhibited } \\
\text { trypsin/ ml blood } \\
\text { serum }\end{array}$} & $0.75 \pm 0.44 m \nabla$ & $0.93 \pm 0.35 \bullet \bullet$ & P0.048 & $1.21 \pm 0.32 \bullet \bullet \bullet \diamond \diamond$ & $P<0.001$ & $P 0.021$ & $\begin{array}{l}r=-0.072 \\
P 0.734\end{array}$ \\
\hline & $\begin{array}{l}\text { Healthy men } \\
(n=18)\end{array}$ & $\begin{array}{l}\text { OA men } \\
(n=13)\end{array}$ & & & & & \\
\hline $\begin{array}{l}\text { Cathepsin } \mathrm{D} n \mathrm{nM} \\
\text { released tyrosine/ } \\
\text { mg protein/min }\end{array}$ & $25.46 \pm 14.54 \square$ & $11.36 \pm 2.72^{\circ \circ}$ & $P 0.015$ & $12.68 \pm 7.83^{\circ}$ & P0.002 & $P 0.937$ & $\begin{array}{l}r=0.538 \\
P 0.071\end{array}$ \\
\hline $\begin{array}{l}\text { AAT mg inhibited } \\
\text { trypsin/ ml blood } \\
\text { serum }\end{array}$ & $0.90 \pm 0.49 \square \Delta \wedge$ & $0.83 \pm 0.18$ & $P 0.810$ & $1.32 \pm 0.43^{\circ 00}$ & $P 0.025$ & $P 0.010$ & $\begin{array}{l}r=0.037 \\
P 0.908\end{array}$ \\
\hline
\end{tabular}

Statistically significant when studied group was compared to a reference group of healthy patients (Mann-Whitney test)

Statistically significant when activities before and on 10th day after surgery were compared (Wilcoxon test)

Statistically significant (Kruskal-Wallis test):

as compared to a healthy women $<55$ y. $-=P 0.006, \cdots P 0.011, \cdots P 0.012$

as compared to a healthy women $>55 \mathrm{y} . \quad-\square P<0.001, \square \times 0.006, \square \square 0.012$

as compared to a healthy men $<55$ y. $-\Delta P<0.001, \Delta \Delta 0.006, \Delta \Delta \Delta P 0.008, \Delta \Delta \Delta \Delta P 0.011$

as compared to a healthy men $>55 \mathrm{y} .-\nabla P<0.001, \nabla \nabla P 0.008$,

as compared to an OA women $<55$ y. $-\bullet P<0.001, \bullet P 0.002, \cdots P 0.004, \cdots \bullet P 0.006, \cdots \cdots P 0.009, \cdots \cdots \bullet 0.013$

as compared to an OA women $>55 \mathrm{y}$. $-{ }^{\circ} P<0.001,{ }^{\circ} P 0.001, \circ 0 \circ 00.016$

as compared to an OA men $<55 \mathrm{y} .-\bullet P 0.002, * P 0.004, * * P 0.009, \cdots * * 0.013$

as compared to an OA men $>55$ y. ${ }^{\diamond} P 0.001, \diamond P 0.001, \diamond \diamond 0 P 0.016$

hol habits due to incomplete data. We can only hypothesize on the enzyme's role in advanced stages of OA. A similar study with initial OA patients is planned.

AAT can quadruple in response to inflammation, its response occurs later than that of $\mathrm{C}$-reactive protein (CRP), another marker of inflammation. Basic inflammatory markers as ESR and CRP peaks till the 5th day following hip or knee replacement and then decreases (Bilgen et al., 2001). Therefore, to rule out the possible role of post-surgical trauma we chose the tenth day for repeated enzymes' activities measurement.
Induction of AAT synthesis by different IL-6-type cytokines in human articular chondrocytes strongly suggests the existence of local acute phase response within the joint. The activity of AAT is high in blood and joint fluid, due to its relatively small molecular mass $(56 \mathrm{kD})$ and its negative charge, but it cannot enter the articular cartilage. In contrast, degrading enzymes released from activated granulocytes, such as the serine proteinase elastase, will readily enter the articular cartilage (Fischer et al., 1999). Therefore, it is important that these proteinases can be inhibited inside the articular cartilage. From the other side Yoshida et al. (1992) have found that sy- 
novial fluid in rheumatoid and septic arthritis contained a large number of white blood cells (WBCs) and high levels of cytokines and lysosomal enzymes, while in contrast the synovial fluid of osteoarthritis and traumatic arthritis did not contain such significant amounts. This may be the reason for the decreased CAT-D activity in blood serum and increased activity of AAT of individuals in our study.

Changes in the proteolytic lysosomal system can be caused by ageing or by ongoing pathological processes like OA (Salminen-Mankonen et al., 2007), increased CAT-D activity that intensifies the degeneration of articular cartilage. The activity of lysosomal proteases was also measured and compared with the severity of the arthritis in few experiments (Mantle et al., 1999; Brömme \& Kaleta, 2002; Lis \& Odrowąż-Sypniewska, 2005; Bowe et al., 2007). The activity of proteases increases when the disease progresses, except in its latest stages. Then, when the cartilage is largely destroyed, the level of enzymatic activity declines. In our study all patients were qualified for total joint replacement because of the advanced stage of joint cartilage destruction. This might be the reason of decreased CAT-D activity in blood serum of studied persons. During the total joint replacement the cartilage is being removed completely from the joint surface and even greater decrease of CAT-D activity should be expected. However, our results did not confirm this decrease.

Reduction of CAT-D and increase of AAT activities maintain proteolytic balance (Tafil-Klawe et al., 2002). Woessner et al. (1973) purified CAT-D and found that it did not digest cartilage at a physiologic $\mathrm{pH}$ and in fact was completely inactive above $\mathrm{pH}$ 7.2. The proteases like CAT-D have $\mathrm{pH}$ optima in the acid range, whereas a normal bloodstream has a $\mathrm{pH}$ of 7.4. Synovial micro vessels contain micro fenestrations that facilitate free diffusion and provide full equilibrium also in joint space. In normal joints this equilibrium exists between plasma and joint fluid. In metabolically ischemic joints, i.e. rheumatoid, where the synovial microvascular supply is unable to meet local nutritional demand, the joint fluid reveals a low $\mathrm{pH}$, optimal for proteolytic enzymes, so their acitivity can increase.

Owen \& Campbell (1999) reported that the lack of CAT-D inhibitor causes its high activity; this can lead to the intensified articular cartilage degeneration. Our results showed that the CAT-D activity in all our patients with osteoarthritis was almost two times lower as compared with healthy patients, and was accompanied by an increased AAT activity. This may confirm the role of AAT in the articular cartilage degeneration process. To explain this hypothesis further studies are required.

The total joint replacement did not influence CAT-D activity in any substantial way on the tenth day after the procedure in comparison with the preoperative parameters, despite the $40 \%$ increase of AAT activity. Thus, the results of our study have not confirmed clear correlation between the increase in the activity of A-1-AT, and the decline in the activity of CAT-D.

Women more often suffer from musculoskeletal inflammatory diseases, such as rheumatoid arthritis or osteoarthritis (Andrianakos et al., 2006; McKean et al., 2007), which is also reflected in our studied group as female patients outnumbered male patients. We found lower activity of CAT-D in OA females' blood serum. After the prosthesis implantation we showed the drop in women's CAT-D activity while surprisingly in OA men there was a slight increase. As these changes were not significant (Table 1) we cannot conclude that CAT-D can describe the intensity of postoperative reaction in either sex subgroup.

In both gender subgroups AAT activities significantly grew after the surgery, which allows us to postulate further studies to find out if this antiprotease activity might be helpful to monitor postoperative responses. Maury et al. confirmed that the concentrations of AAT were the highest on the fourth postoperative day (mean changes $+35 \%, P<0.01$ ) (Maury et al., 1983). The analysis of our patients with degenerative disease of hip and knee joints revealed statistically significant difference in AAT activity before and after the surgical treatment. Simultaneously, in our study the differences in CAT-D activity before and on the tenth day after the total joint replacement were not statistically significant. Perhaps, such difference would have been found in an additional assessment of CAT-D activity in a longer follow up.

The changes in AAT activity were significantly higher in men's blood serum, what might suggest a more intense postoperative reaction in male patients. This may be consistent with Chung et al. results who found higher inflammatory markers after spine surgery in elderly male patients (Chung et al., 2011).

Epidemiologic data confirm the age related factor in OA development (Shane Anderson \& Loeser, 2010; Guillemin et al., 2011). The sharp increase in incidence of symptomatic knee OA after age of 50 in women suggests an influence of menopausal changes of hormonal status. The prevalence of radiographically defined OA of the hip is higher in men than in women (Okoński et al., 1990; Gerasimov, 2005). Degenerative changes causing typical radiological image are found in $50 \%$ of the population aged over 65 and in as much as $80 \%$ of the population aged over 75 (Bagge et al., 1991). In our material we did not find any preoperative differences in biochemical activity of the assessed enzymes in correlation to patient's age. The higher pre- and postoperative CAT-D activity changes were found in patients under 55 years old.

Higher activity of the CAT-D inhibitor - AAT, which is released in large amounts from immunologic system cells, especially after extensive surgical treatment, might suggest faster tissue regeneration after surgical treatment in younger patients (Ziętek et al., 1996). Due to the ageing process, the function of proteolytic enzymes system becomes impaired; this makes various cells and tissues susceptible to proteolysis (Skrzydlewska et al., 2001). In the blood serum of our patients, especially those above 55 years old, the activity of CAT-D was higher than in others, which may suggest an increased proteolysis at an elderly age.

Among different locations of joint degeneration the most frequent are hand, knee and hip (Pereira et al., 2011). Since Salvati et al.'s (1977) article it seems there was no report on CAT-D activity in OA patients assessed neither in blood serum nor in joint fluid. The authors are aware of certain limitations of comparison of ours and Salvati's results, as the synovial joint content of enzymes is not identical with blood serum. These authors (Salvati et al., 1977) showed a higher synovial activity of CAT-D in hip and lower — in knee joints. In our study the CAT-D activity was measured in OA patients' blood serum. In hip OA patients the CAT-D activity was similar before and after the total replacement and both values were approximately two times lower as compared to the reference group. Based on natural history and intraoperative findings it is well established that hip OA develops with smaller synovial reaction than knee OA, and 
this fact may explain the differences between enzyme activity in either joint $\mathrm{OA}$.

Further investigations with a larger group, more data on alcohol intake and smoking (as A1AT activity depends on these habits) are necessary before stating more univocal conclusions.

\section{REFERENCES}

Abboud RT, Chalmers A, Gofton JP, Richter AM, Enarson DA (1992). Relationship between severity of rheumatoid arthritis and serum alpha 1-antitrypsin. J Rheumatol 18: 1490-1495. Erratum in: I Rheumatol 19: 329.

Andrianakos AA, Kontelis LK, Karamitsos DG, Aslanidis SI, Georgountzos AI, Kaziolas GO, Pantelidou KV, Vafiadou EV, Dantis PC, ESORDIG Study Group (2006) Prevalence of symptomatic knee, hand, and hip osteoarthritis in Greece. The ESORDIG study. I Rheumatol 33: 2507-2513.

Bagge E, Bjelle A, Edén S, Svanborg A (1991) Osteoarthritis in the elderly: clinical and radiological findings in 79 and 85 year olds. Ann Rheum Dis 50: 535-539.

Bao JP, Chen WP, Feng J, Hu PF, Shi ZL, Wu LD (2010) Leptin plays a catabolic role on articular cartilage. Mol Biol Rep 37: 3265-3272.

Bilgen O, Atici T, Durak K, Karaeminoğullari, Bilgen MS (2001) C-reactive protein values and erythrocyte sedimentation rates after total hip and total knee arthroplasty. J Int Med Res 29: 7-12.

Bonnet CS, Walsh DA (2005) Osteoarthritis, angiogenesis and inflammation. Rheumatology 44: 7-16.

Bowe EA, Murray RC, Jeffcott LB, Davies ME (2007) Do the matrix degrading enzymes cathepsins B and D increase following a high intensity exercise regime? Osteoarthritis Cartilage 15: 343-349.

Brömme D, Kaleta J (2002) Thiol-dependent cathepsins: pathophysiological implications and recent advances in inhibitor design. Curr Pharm Des 8: 1639-1658.

Brooks P (2003) Inflammation as an important feature of osteoarthritis. Bull World Health Organ 81: 689-690.

Chevalier X, Groult N, Emod I, Planchenault T (1996) Proteoglycan degrading activity associated with the $40 \mathrm{kD}$ a collage-binding fragment of fibronectin. BrJ Rheumatol 35: 506-514.

Chung YG, Won YS, Kwon YJ, Shin HC, Choi CS, Yeom YS (2011) Comparison of serum CRP and procalcitonin in patients after spine surgery. J Korean Neurosurg Soc 49: 43-48.

Fischer DC, Siebertz B, van de Leur E, Schiwy-Bochat KH, Graeve L, Heinrich PC, Haubeck HD (1999) Induction of alpha1-antitrypsin synthesis in human articular chondrocytes by interleukin-6-type cytokines: evidence for a local acute-phase response in the joint. Arthritis Rheum 42: 1936-1945.

Garnero P, Delmas PD (2003) Biomarkers in osteoarthritis. Curr Opin Rheumatol 15: 641-646.

Gerasimov AM (2005) Specific features of protease and antiprotease activity of blood in women with external endometriosis. Klin Lab Diagn 3: 14-16.

Guillemin F, Rat AC, Mazieres B, Pouchot J, Fautrel B, Euller-Ziegler L, Fardellone P, Morvan J, Roux CH, Verrouil E, Saraux A, Coste J, 3000 Osteoarthritis group (2011) Prevalence of symptomatic hip and knee osteoarthritis: a two-phase population-based survey. Osteoarthritis Cartilage 19: 1314-1322.

Handley CJ, Mok MT, Ilic MZ, Adcocks C, Buttle DJ, Robinson HC (2001) Cathepsin-D cleaves aggrecan at unique sites within the interglobular domain and chondroitin sulfate attachment regions that are also cleaved when cartilage is maintained at acid pH. Matrix Biol 20: 543-553.

Hoaglund FT, Steinbach LS (2001) Primary osteoarthritis of the hip: etiology and epidemiology. I Am Acad Orthop Surg 9: 320-337.

Karnaukhova E, Ophir Y, Golding B (2006) Recombinant human alpha-1 proteinase inhibitor: towards therapeutic use. Amino Acids 30: 317-332.

Keyszer GM, Heer AH, Kriegsmann J, Geiler T, Trabandt A, Keysser M, Gay RE, Gay S (1995) Comparative analysis of cathepsin $\mathrm{L}$, CAT-D, and collagenase messenger RNA expression in synovial tissues of patients with rheumatoid arthritis and osteoarthritis, by in situ hybridization. Arthritis Rheum 38: 976-984.

Lis K, Odrowaz-Sypniewska G (2005) Role of cathepsin K in the pathogenesis of degenerative changes in joints. Ortop Traumatol Rebabil 7: 361-364.

Lis K, Sypniewska G, Nowacki W (2006) IGF-1, cytokines and biochemical bone turnover markers in synovial fluid and serum of patients with primary and secondary osteoarthritis of the hip. Biochemia Medica 16: 127-136.

Mantle D, Falkous G, Walker D (1999) Quantification of protease activities in joint fluid from rheumatoid and osteoarthritis cases: com- parison with antioxidant and free radical damage markers. Clin Chim Acta 284: 45-58.

Maury CP, Teppo AM, Raunio P (1983) The acute phase response and its relation to amyloid A degrading activity in serum of patients with rheumatoid arthritis undergoing total joint replacement. Eur J Clin Invest 13: 73-78.

McKean KA, Landry SC, Hubley-Kozey CL, Dunbar MJ, Stanish WD, Deluzio KJ (2007) Gender differences exist in osteoarthritic gait. Clin Biomech 22: 400-409.

Mycek KJ. Cathepsins (1970) In Methods in Enzymology Perlmann GE, Lorand L, eds, pp 285-315. Academic Press, New York.

Okoński M, Gregosiewicz A, Gil L (1990) The protease-antiprotease system in pathogenesis of transient arthritis of a single joint in children. Chir Narzadów Ruchu Ortop Pol 3: 205-208 (in Polish).

Olewicz-Gawlik A, Stryjska M, Lacki JK (2004) Molecular mechanisms of osteoarthritis. Pol Arch Med Wew 111: 629-634 (in Polish).

Olszewska D, Drewa T, Makarewicz R, Drewa J, Wozniak A, Maciak R (2001) Significance of cathepsin B and D in physiologic and pathologic processes. Pol Merk Lek 10: 65-70 (in Polish).

Owen CA, Campbell EJ (1999) The cell biology of leukocyte mediated proteolysis. J Leukoc Biol 65: 137-150.

Pearle AD, Scanzello CR, George S, Mandl LA, DiCarlo LF, Peterson M, Sculco TP, Crow MK (2007) Elevated high-sensitivity C-reactive protein levels are associated with local inflammatory findings in patients with osteoarthritis. Osteoarthritis Cartilage 15: 516-523.

Pereira D, Peleteiro B, Araújo J, Branco J, Santos RA, Amos E (2011) The effect of osteoarthritis definition on prevalence and incidence estimates: a systematic review. Osteoarthritis Cartilage 19: 1270-1285.

Popko J, Zalewska A, Sierakowski S, Macias T, Knaś M, Zwierz K, Sredzińska K (2005) Activity of N-acetylo-beta-hexosamninidase in joint fluid from knee and serum of patients with rheumatoid arthritis and osteoarthritis. Przegl Lek 62: 650-652 (in Polish).

Ruiz-Romero C, Lopez-Armada MJ, Blanco FJ (2005) Proteomic characterization of human normal chondrocytes: a novel tool for the study of osteoarthritis and other rheumatics disease. Proteomics 5: 48-59.

Salminen-Mankonen HJ, Morko J, Vuorio E (2007) Role of cathepsin $\mathrm{K}$ in normal joints and in the development of arthritis. Curr Drug Targets 8: 315-23.

Salvati EA, Granda JL, Mirra J, Wilson PD Jr (1977) Clinical, enzymatic and histological study of synovium in coxarthrosis. Int Orthop 1: $39-42$.

Schneider U, Schmidt-Rohlfing B, Knopf U, Breusch SU (2002) Effects upon bone metabolism following total hip and total knee total joint replacement. Pathobiology 70: 26-33.

Shane Anderson A, Loeser RF (2010) Why is osteoarthritis an agerelated disease? Best Pract Res Clin Rheumatol 24: 15-26.

Skrzydlewska E, Sulkowska M, Makieła M (2001) Changes in the intracellular protein degradation during aging. Post Hig Med Dośw 3: 567-581 (in Polish).

Stoka V, Turk V, Turk B (2007) Lysosomal cysteine cathepsins: signaling pathways in apoptosis. Biol Chem 388: 555-560.

Stürmer T, Brenner H, Koenig W, Günther KP (2004) Severity and extent of osteoarthritis and low grade systemic inflammation as assessed by high sensitivity $C$ reactive protein. Ann Rheum Dis 63: 200-205.

Sun S, Fang K, Zhao Y, Yan X, Chang X (2012) Increased expression of alpha 1-anti-trypsin in the synovial tissues of patients with ankylosing spondylitis. Clin Exp Rheumatol 30: 39-44.

Szczeklik E (1974) Enzymologia kliniczna, Warszawa, PZWL (in Polish).

Tafil-Klawe M, Wozniak A, Drewa T, Ponikowska I, Drewa J, Drewa G, Wlodarczyk K, Olszewska D, Klawe J, Kozlowska R (2002) Ozone therapy and the activity of selected lysosomal enzymes in blood serum of patients with lower limb ischaemia associated with obliterative atheromatosis. Med Sci Monit 7: 520-525.

Ucar HI, Tok M, Atalar E, Dogan OF, Oc M, Farsak B, Guvener M, Yilmaz M, Dogan R, Demircin M, Pasaoglu I (2007) Predictive significance of plasma levels of interleukin-6 and high-sensitivity Creactive protein in atrial fibrillation after coronary artery bypass surgery. Heart Surg Forum 10: 131-135.

Woessner JF Jr (1973) Purification of CAT-D from cartilage and uterus and its action on the protein-polysaccharide complex of cartilage. J Biol Chem 248: 1634-1642.

Yoshida K, Kobayashi K, Yamagata N, Iwabuchi H, Katsura T, Sugihara S, Negishi M, Ide H, Mori Y, Takahashi T (1992) Inflammatory cytokines and enzymes in synovial fluid of patients with rheumatoid arthritis and other arthritides. Int Arch Allergy Immunol 98: 286-292.

Ziętek Z, Ziętek-Iwan I, Kotschy M, Tyloch F (1996) Activity of alpha 1-antitrypsin in blood of patients with prostatic tumor. Pol Tyg Lek 51: 89-90 (in Polish). 